\title{
SUSTAINABILITY ACCOUNTING - HISTORICAL DEVELOPMENT AND FUTURE PERSPECTIVES OF THE DISCIPLINE
}

\author{
DOI: 10.17261/Pressacademia.2021.1475 \\ PAP- V.14-2021(1)-p.1-4
}

\section{Norbert Gyorgy Gacser ${ }^{1}$, Karoly Szoka²}

${ }^{1}$ University of Sopron, Alexander Lamfalussy Faculty of Economics, István Széchenyi Management and Organisation Sciences Doktoral School, Sopron, Hungary. gacsernorbert@gmail.com, ORCID: 0000-0002-0944-2986

${ }^{2}$ University of Sopron, Alexander Lamfalussy Faculty of Economics, Sopron, Hungary. szoka.karoly@uni-sopron.hu, ORCID: 0000-0003-4880-1715

To cite this document

Gacser,N., Szoka, K. (2021). Sustainability accounting - historical development and future perspectives of the discipline. PressAcademia Procedia (PAP), 14,.1-4

Permanent link to this document: http://doi.org/10.17261/Pressacademia.2021.1475

Copyright: Published by PressAcademia and limited licensed re-use rights only.

\section{ABSTRACT}

Purpose- The purpose of this study is two folded. In one hand it intends to provide an overview of the historical formation and development of the scientific field of sustainability accounting, starting from the history of it's predecessor disciplines. To this end the history of accountancy is examined first, followed by the development of the idea of sustainability. Then the birth and advances of sustainability accounting are presented. The secondary goal of this research is to define the future perspectives of sustainability accounting, derived from it's origins.

Methodology- This study is a historical literature review, employing an interpretative and synthesising approach by a recombination of works done in the field. The possible sources of the research drawn into comparison are books, peer-reviewed journals, conference proceedings and papers, dissertations and thesises. The final selection put a high emphasis on peer-reviewed journals as evaluated sources.

Findings- The analysis reveals, that accountancy and the idea of sustainability have a long history and clearly defined definitions, while sustainability accounting is yet to be demarcated from other scientifical fields. There is not one universally accepted definition of sustainability accounting to day, also it's taxonomic placement and mandatory components are yet to be agreed on. Along with the absence of a uniform definition, opinions (and definitions) similarly concur on the three main factors of sustainability accounting, which are environmental, social and economical factors (see also as three bottom line, or TBL). Besides, researches can be grouped in two main directions: a theoretical direction, emphasizing accountability, contribution to sustainability and steps leading to sustainability (strategic) and another, consisting mainly of applicable management tools (eg. measurements, information system, reporting).

Conclusion- Based upon the analyisis, there are similar characteristics in the various definitons of sustainability accounting, yet it is still an inhomogeneous, multi directional and constantly evolving field of research. Until today the most known standards were laid down with Gray's Sustainability Accounting Principles (2002) and Lambertons sustainability accounting framework (2005). We concluded to a definition of sustainability accounting as the following: Sustainability accounting is primarly a practice of measuring, analyzing and reporting on social and environmental impacts of companies, as well as on their economical sustainability, and secondarily It is also a set of principles and guidelines for the implementation of environmental awareness and social justice into the economical viewpoint. The lack of quicker development in sustainability accounting research for the last decade is likely a product of the crisis of 2009. Citing Gray "there is little or no prospect of widespread, systematic reporting by corporations without a major regulatory initiative" and to solve the crisis and to handle it's consequences must have had a priority above all, which included sustainability problems. The latest steps taken by the EU will most likely promote development. Presumably, the combination between practical needs and the work of theoretical authors will eventually lead to the development of a more crystallized and widely accepted sustainability accounting discipline on the long run, as much as it happened in the history of accountancy, with the urging need for sustainability as the accelerator of the process.

Keywords: Sustainability, sustainability accounting, environmental accounting, corporate social responsibility JEL Codes: Q56, M41, Z13

\section{INTRODUCTION}

The purpose of this study is twofolded. On one hand it aims to provide an overview of the historical formation and development of the scientific field of sustainability accounting, emerging from the history of It's two main predecessor disciplines. To this end, it first examines 
the history of accountance and then the development of the idea of sustainability. Afterwards, the milestones of formation and development of sustainability accounting are described. Finally, as a secondary goal the research intends to determine future perspectives of sustainability accounting based on current trends.

\section{LITERATURE REVIEW}

There is a plethora of studies available on sustainability accounting in the literature, in the period of writing this paper "sustainability accounting" as a set of keywords ends in above 18000 results on Web of Science. By the nature of the topic the related fields of science vary richly from ecology, through political science and law, to economy, partially because it's a generic term and also a collective concept. Narrowing down the search for the field of economy and business most of the studies included addressed some specific topic, or one side of sustainability accounting. In this paper the focus is put on the historical development of the discipline to get a short overview of progress made so far and also to asses future trends. To date the most cited studies intending to give a summary on the topic of sustainability accounting are Matthews (1997), Lamberton (2005), Thomson (2007), Burrit and Schaltegger (2010), while the most recent comprehensive study we utilized was by Hyrslova J., Beckova H., Kubankova M. (2015). All of the above mentioned works focus on sustainability accounting's history, as a consequence the starting points are placed rather in recent history of the end of the $20^{\text {th }}$ century. Our paper attempts to provide an overview dating further back by examining the historical development of the initial disciplines first, then presenting the development of sustainability accounting in an organical continuity. Examining available scientific sources to understand the historical development of accountancy and the development of the idea of sustainability this paper mainly utilizes two comprehensive overviews, the "History of accountancy. A chronological approach" by Cindiana, M., Cindea, IM, Ciurariu, G., Trifu, A., Durdureanu, C. and "Sustainable development historical roots of the concept" by Pisani, J.D.

Accounting is not an achievement of the modern times. The rudimentary accounting (inventory of goods) is probably the same age as humanity. It's development is closely linked with the great discoveries of mankind, including the emergence of the trade of goods, the formation of currency, or the discovery of paper. Accounting records were found studying the Codex of Hammourabi from the age of antiquity, also there are traces of proof for the existence of the accounting profession as part of Egyptian, Roman and Greek history. Modern accounting began its conquest journey from Italy, following the work of Luca Paccioli, on the "double entry" basis laid down in 1494 in the "Summa de arithmetica, geometria, proportioni et proportionalita". It was characteristic of Italian companies in the 16th century to have several international interests and subsidiaries, which used - and consequently disseminated - the Paccioli accounting system as a uniform practice. Some of these branches had an influence to gain government support to propagate their accounting system generally, thus accelerating its widespread adoption in several countries. Many of the basic practical achievements known today have been developed over the 16th century, such as the use of "closing accounts" or the construction of the income statement. In the 17th century, the practice of using sub-accounts specified for individual corporate activity became widespread, and the term "balance sheet" (introduction of the closing balance sheet) began to be used. In the 18th century, the use of accounting became widespread in the public sector, the use of technical accounts were introduced and valuation methods were developed. Eventually, during the 19th - and even more so in the 20th - century, accounting became a clearly independent and universally recognized discipline that went beyond "econometrics", as a technical method used to calculate values and was widely used to study business (Cindiana, M., Cindea, IM, Ciurariu, G., Trifu, A., Durdureanu, C., 2011).

The impact of demand for raw materials on the environment has been a constant issue in the history of mankind: the decline of soil fertility, salinisation and the consequences of deforestation have occupied us since ancient times. In a modern sense these are sustainability issues. However, problems only became global as a result of the Industrial Revolution. From the end of the 18th century the idea of "development" became the flagship of the West, according to which civilization was constantly (and linearly) moving towards a desirable state from a scientific (technological), moral, and material point of view. As the prospects of human existence intertwined with economic development from the end of the 18th century the need for growth and material development compelled people to transform nature into consumer goods as much and as quickly as possible. As a part of this, the destruction of the landscape was necessary and acceptable as they assigned value only to things produced by the industry, marketed for sale. As the benefits of the world economic system flowed primarily to countries with advanced industries, the gap between rich and poor societies has widened exponentially. Industrial development has caused worrying environmental degradation through a large-scale exploitation of raw materials. The idea of sustainability has emerged as an opposing idea to "progress". The 20th century began with an optimistic outlook, with technological advances providing almost limitless opportunities that were broken by the two world wars and the economic crisis that followed. From the '50s and onwards, the seemingly unstoppable economic recovery brought back initial optimism, all the way to the onset of an impending ecological and / or economic crisis, increasingly visioned at the end of the 20th century. The latter has led people to reconsider their vision of limits of growth. Different ideas about development, sustainability, and growth have moved in a new direction since the '70s toward sustainable development, and the myth of progress has slowly lost ground due to its impact on society and the environment (Pisani, J.D., 2006). Linking the concept of sustainability and development together has spread since the '80s, with the term "sustainable development" first being used by the International Union for Conservation of Nature in it's World Conservation Strategy. As a milestone the UN has commissioned a group of 22 people to define long-term environmental strategies for the international community. This was the World Commission on Environment and Development (WCED), better known as the Brundtland Commission, which presented it's report in 1987 titled 'Our Common Future'. As the Brundtland Commission stated in 1987, "sustainable development is development, that meets the needs of present generations without compromising the ability to meet the similar needs of future generations. The concept interprets sustainable economic, ecological and social development in unity" (WCED, 1987). The Brundtland report was not left without any criticism: conservative critics interpreted sustainability as stagnation, which is not enough to meet the needs of growing populations, arguing that human ingenuity is a task of coping with growth and development, making any sustainable development policies unnecessary (Mitcham C ., 1995). 
To implement sustainability through accounting practices has became a popular research topic from the 90 's. As a consequence, various regulatory frameworks, philosophical trends, training programs and empirical researches enriched the organically expanding literature. Still, an accepted and uniform definition of sustainability accounting has not been developed in the scientific literature to date. All that can be said, is that the literature is constantly growing and in order to classify researches into this field of science it must be in line with the wording of the Brundtland Committee of 1987. The literature of the last two decades a level of convergence could be observed. Studying researches publicized it seems relatively consistent regarding the 3 main aspects of sustainability accounting, which are the social, economic and environmental dimensions. There's also a purification in approaches, researches can be grouped in two main directions: a theoretical direction that emphasizes accountability, contribution to sustainability and steps leading to sustainability (strategic aspect) and another one, that focuses primarily on applicable management tools (e.g., metrics, information system, reporting), being thematically close to the discipline of financial accounting (Matthews, MR, 1997; Hódiné-Hernádi, B., 2014). As a milestone, Gray's work, presented at the World Summit on Sustainable Development in Johannesburg (2002) "Sustainability Accounting Guidelines" incorporated the 3 most important sustainability accounting methods into a structure of classical financial accounting (sustainability costs, stockpiling natural capital, inputoutput analysis) (Gray, 2002). To date, this is the most frequently cited methodological material on the subject. Geoff Lamberton created a "standard" sustainability accounting framework in 2005 by consolidating different approaches on the topic (building heavily on basic definitions laid down by Gray). The result of his research is a comprehensive framework, built on the main elements known in the modern literature of sustainability accounting (principles, tools, metrics, models), total cost accounting (Atkinson, 2002), and the "three bottom line" (TBL) (Elkington, 1999; Westing, 1996).

Formal rules of sustainability reporting started to take shape over the last decades. In 1997 the Global Reporting Initiative (GRI) was established by the Coalition for Environmentally Responsible Economies (CERES) and the United Nations Environment Program (UNEP), with the aim to create rules for reporting economic, environmental and social dimensions of organizations (the three bottom line) (Hyrslova J., Beckova H., Kubankova M., 2015). The European Union contributed to establish a regulatory framework for sustainability reporting (nonfinancial reporting): a directive was adopted in 2014 obliging a large number of companies (approximately the top 11.700) to disclose nonfinancial and diversity information (2014 / Directive 95 / EC). To facilitate it's implementation, the European Commission published a guide in June 2017 to help companies publish environmental and social information, which was complemented by the 2019 guidelines on climate change. On 21th April 2021, the Commission adopted a proposal for a Corporate Sustainability Reporting Directive (CSRD), which amended the existing reporting requirements of the NFRD. The proposal applies to all large companies and all companies listed on regulated markets (except listed micro-enterprises), it ordains the auditing of the reported information and introduces detailed reporting requirements. In addition, there's a shift towards a mandatory Community Sustainability Reporting Standard: The European Financial Reporting Advisory Group (EFRAG) has been appointed to develop drafts of standards. The first set of standards will be developed by October 2022, aligned with EU policies and contributing to international standardization initiatives (EU Consultation, 2020).

\section{DATA AND METHODOLOGY}

This study is a historical literature review, employing an interpretative and synthesising approach by a recombination of works done in the field. The possible sources of the research drawn into comparison were books, peer-reviewed journals, conference proceedings and papers, dissertations and thesises. Final selection put a high emphasis on peer-reviewed journals as evaluated sources.

\section{FINDINGS}

The idea of accounting and sustainability have a long history with clearly defined definitions by now, while sustainability accounting cis yet be clearly separated and individualized. There is not one generally accepted definition of sustainability accounting to date, yet views on it's taxonomy and it's mandatory components are slowly converging. Based on the present research, similar characteristics can be found in different definitions of sustainability accounting, but it remains an inhomogeneous, multidirectional and constantly evolving field of research. The best-known - scientifical - standards are defined by Gray's Sustainability Accounting Principles (2002) and Lamberton's Sustainability Accounting Framework (2005). In the absence of a uniform definition still there seems to be consensus on the three main factors of sustainability accounting, which are the environmental, social and economic dimensions known as the three bottom line or TBL (Elkington, 1999). Besides the available researches can be grouped in two main directions: one theoretical, which emphasizes accountability, contribution to sustainability and steps towards sustainability (strategic perspective), and another, which mainly consists of applicable management tools (eg metrics, information system, reports). Based on these findings we could formulate Our own definition of sustainability accounting.

\section{CONCLUSION}

Based upon the analyisis, there are similar characteristics in the various definitons of sustainability accounting, yet it is still an inhomogeneous, multi directional and constantly evolving field of research. Until today the most known standards were laid down with Gray's Sustainability Accounting Principles (2002) and Lambertons sustainability accounting framework (2005). We concluded to our own definition of sustainability accounting as the following: Sustainability accounting is two folded. Primarly It is a practice of measuring, analyzing and reporting on social and environmental impacts and economical sustainability of companies. Secondarily it is a set of principles and guidelines for the implementation of environmental awareness and social justice into the economical viewpoint.

The lack of quicker development in sustainability accounting research for the last decade is likely a product of the crisis of 2009. Citing Gray "there is little or no prospect of widespread, systematic reporting by corporations without a major regulatory initiative" and to solve the crisis and to handle it's consequences must have had a priority above all, which includes sustainability problems. Differences in global warming, pollution, quality of life and income distribution are an increasingly pressing problem, and the increase in the scientific results of 
sustainability accounting, the development of the discipline and the spread of knowledge of its methods can greatly contribute to solving them. Issues of sustainability, corporate social responsibility and the publication of reports on them have so far stimulated research interest in these areas and these trends are sure to continue. "It is hardly conceivable for a future where these issues are not considered important. A much more likely scenario is a future in which the integration of sustainability and social and environmental responsibility is seen as a prerequisite for any successful organization "(De Villiers, C. \& Maroun, W., 2018) and as a proof of that the late steps made by the European Union could be a valid proof. Presumably, the combination between practical needs and the work of theoretical authors will eventually lead to the development of a more crystallized and widely accepted sustainability accounting discipline on the long run, as much as it happened in the history of accountancy, with the urging need for sustainability as the accelerator of the process. Most possibly We will see obligatory rules for sustainability reports put into tacit legislation by many countries world wide in the following years, especially within the Community. Various types of implementation will add to the practical knowledge accumulated. As a consequence the general standards of sustainability accounting will likely become more formalized worldwide.

\section{REFERENCES}

Agudelo, M.A., Johannsdottir, L., \& Davidsdottir, B. (2019). A literature review of the history and evolution of corporate social responsibility. International Journal of Corporate Social Responsibility, 4, 1-23.

Atkinson, G. (2002). Measuring corporate sustainability. Journal of Environmental Planning and Management, 43(2), $235-244$.

Ascani, I., Ciccola, R., \& Chiucchi, M. S. (2021). A Structured Literature Review about the Role of Management Accountants in Sustainability Accounting and Reporting. Sustainability, 13(4), 2357.

Cindiana, M., Cindea, I. M., Ciurariu, G., Trifu, A., Durdureanu, C.(2011). History of accountancy. A chronological approach. International Conference on Financial Management and Economics. IACSIT. Singapore.

Corporate sustainability reporting. EU Consultation, 2020.02.20., Financial Stability, Financial Services and Capital Markets Union Source: https://ec.europa.eu/info/business-economy-euro/company-reporting-and-auditing/company-reporting/corporate-sustainabilityreporting_en Downloaded on: 2021.09.20.

Elkington, J. (1999). Triple bottom-line reporting: Looking for balance. Australian CPA (March), 19-21.

Gray, R. (1994). "Corporate Reporting for Sustainable Development: Accounting for Sustainability in 2000AD". Environmental Values. 3 (1): 17-45.

Gray, R. (2002). The social accounting project and accounting organizations and society. Privileging engagement, imaginings, new accountings and pragmatism over critique? Accounting Organizations and Society, 27, 687-708.

Hódiné-Hernádi, B. (2014): A fenntarthatósági számvitel, mint a számvitel új iránya. Ekonomické štúdie - teória a prax, ISBN 978-80-9712512-

Hyrslova J., Beckova H., Kubankova M. (2015). Sustainability Accounting: Brief History And Perspectives. The 9th International Days of Statistics and Economics, Prague, September 10-12.

Lamberton, G. (2005). Sustainability accounting - a brief history and conceptual framework. Accounting Forum 29, 7-26. Elsevier

Matthews, M. R. (1997). Twenty-five years of social and environmental accounting research. Is there a silver jubilee to celebrate?". Accounting, Auditing \& Accountability Journal, 10 (4): 481-531.

Mitcham C. (1995). The concept of sustainable development: its origins and ambivalence. Technol Soc 17:311 - 326.

Păunică,M. \& Mocanu,M.(2017).Green controlling - concept and practice. Proceedings of the International Conference on Business Excellence,11(1) 1137-1145. https://doi.org/10.1515/picbe-2017-0117

Pisani, J.D. (2006). Sustainable development - historical roots of the concept. Environmental Sciences, 3, 83-96.

Previts, G. (2010). A global history of accounting, financial reporting and public policy. ISBN: 9781315108032

Şakar, A. Y. (2016). Development of Sustainability Accounting Standards. Eurasian Business \& Economics Journal, S1, 43-52.

Schaltegger, S., Burrit R.L. (2010). Journal of World Business, 45, 375-384.

Thomson, I. (2007). Mapping the terrain of sustainability accounting. In J. Unerman, J. Bebbington, \& B. O’Dwyer (Eds.), Sustainability Accounting and Accountability, 19-37.

Villiers, C., \& Maroun, W. (2017). The future of sustainability accounting and integrated reporting. Sustainability accounting and Integrated Reporting, 163-170.

Volkova, O.N., (2012). Born in Italy: On the origins of management accounting concept (Родом из Италии: у истоков управленческого учета и анализа). Finansy I Business. 4, 216-228.

WCED (World Commission on Environment and Development). 1987. Our common future. Oxford: Oxford University Press. 